\title{
Error budget analysis of SCIAMACHY limb ozone profile retrievals using the SCIATRAN model
}

\author{
N. Rahpoe ${ }^{1}$, C. von Savigny ${ }^{1, *}$, M. Weber ${ }^{1}$, A.V. Rozanov $^{1}$, H. Bovensmann ${ }^{1}$, and J. P. Burrows ${ }^{1}$ \\ ${ }^{1}$ Institute of Environmental Physics, University of Bremen, Otto-Hahn-Allee 1, \\ 28359 Bremen, Germany \\ *now at: Institute of Physics, Ernst-Moritz-Arndt-University of Greifswald, Felix-Hausdorff-Str. 6, \\ 17489 Greifswald, Germany
}

Correspondence to: N. Rahpoe (nabiz@iup.physik.uni-bremen.de)

Received: 18 April 2013 - Published in Atmos. Meas. Tech. Discuss.: 27 May 2013

Revised: 2 September 2013 - Accepted: 15 September 2013 - Published: 25 October 2013

\begin{abstract}
A comprehensive error characterization of SCIAMACHY (Scanning Imaging Absorption Spectrometer for Atmospheric CHartographY) limb ozone profiles has been established based upon SCIATRAN transfer model simulations. The study was carried out in order to evaluate the possible impact of parameter uncertainties, e.g. in albedo, stratospheric aerosol optical extinction, temperature, pressure, pointing, and ozone absorption cross section on the limb ozone retrieval. Together with the a posteriori covariance matrix available from the retrieval, total random and systematic errors are defined for SCIAMACHY ozone profiles. Main error sources are the pointing errors, errors in the knowledge of stratospheric aerosol parameters, and cloud interference. Systematic errors are of the order of $7 \%$, while the random error amounts to $10-15 \%$ for most of the stratosphere. These numbers can be used for the interpretation of instrument intercomparison and validation of the SCIAMACHY V 2.5 limb ozone profiles in a rigorous manner.
\end{abstract}

\section{Introduction}

Ozone is an important trace gas in the Earth's atmosphere (Chapman, 1930; Crutzen, 1970; Molina and Rowland, 1974). It is the main absorber of solar UV radiation in the stratosphere and mesosphere, and is one of the climate gases contributing to global warming (Kiehl and Trenberth, 1997). Anthropogenic increase of ozone-depleting substances (ODS) such as chlorofluorocarbons (CFCs) in the stratosphere up to the end of the 1990s led to the longterm decline in ozone (WMO Assessment, 2006). The Montreal Protocol in 1987 and its later amendments banned the production of CFCs and related ODS. Several studies indicate that ozone has been recovering since the late 1990s (Newchurch et al., 2003; Steinbrecht et al., 2009; Jones et al., 2009). Different satellite missions with the instruments TOMS, SAGE I-III, SBUV, HALOE, SABER, MLS, SCIAMACHY, GOME, GOMOS, and MIPAS have contributed to investigating and understanding stratospheric ozone over the past three decades. SCIAMACHY (Scanning Imaging Absorption Spectrometer for Atmospheric CHartographY) is one of the instruments on board the Envisat platform, which was launched in 2002. It performed measurements for about $10 \mathrm{yr}$ in three observation modes, i.e. nadir, limb, and occultation (Bovensmann et al., 1999, 2002). Unfortunately, contact to the Envisat platform was lost on 8 April 2012, and the official mission end was declared in early May 2012. In the limb mode the spectral backscattered radiation from $\mathrm{UV}$ to the visible range is used to retrieve ozone number density profiles. A zonal mean time series of SCIAMACHY limb ozone version 2.3 is shown in Fig. 1 for various latitude bands at the $49 \mathrm{hPa}$ level. These time series, which include the entire SCIAMACHY data set from 2002 to 2011, show the annual and semiannual variability of the stratospheric ozone signal, which needs to be considered in order to extract long-term trends in stratospheric ozone (Jones et al., 2009; Steinbrecht et al., 2009, 2011). A detailed error characterization of the SCIAMACHY limb ozone data set is very helpful when interpreting validation results obtained 
by comparing SCIAMACHY limb ozone measurements with other concurrent data sets (Mieruch et al., 2012). The aim of this paper is to provide an estimate of the total error in the SCIAMACHY limb ozone profile retrievals using the SCIATRAN radiative transfer model.

The total error is a combination of accuracy and precision estimates of the ozone profiles (Cortesi et al., 2007). The accuracy (systematic error) and the precision (random error) have to be precisely estimated in order to explain the bias or the difference between two independent instruments. The retrieved ozone profiles depend on parameter settings in the SCIATRAN radiation transfer model (Rozanov et al., 2005) that is used as the forward model in the limb ozone retrieval. The question arises as to how accurately these parameters are known, and how their uncertainties result in errors in the retrieved ozone profiles. Until now there have only been estimates of the influence of cloud parameter uncertainties on the retrieved SCIAMACHY ozone profiles available (Sonkaew et al., 2009) that typically range between 1 and $3 \%$ in the stratosphere. In the present paper the investigation of the influence of additional physical parameters on the retrieved ozone profiles using SCIATRAN is presented. Deriving possible uncertainties in the retrieved ozone profiles from different parameter errors in the forward model, a detailed total error budget can be established.

The method used in this paper in order to establish a total error budget has been implemented by von Savigny et al. (2005a) for the OSIRIS limb ozone retrievals. We followed similar procedures in order to establish an error budget for SCIAMACHY ozone profile retrievals. The first step is to estimate the uncertainties for different geometrical and physical parameters, and in the second step, the impact of parameter uncertainties on the retrieved ozone profiles is calculated. The impacts of albedo, stratospheric aerosol extinction coefficient, temperature, pressure, ozone cross-section choice, clouds, temperature dependency of the ozone absorption cross section, and signal-to-noise ratio on the retrieved ozone profiles are examined and analysed. In Sect. 2 the SCIATRAN model and ozone retrieval method is described. In Sect. 3 the parameters used in the SCIAMACHY ozone profile retrieval, their uncertainties, and the effects of each parameter on the retrieved ozone profiles are presented. In Sects. 4 and 5 the total error budget and the main results of the work are discussed.

\section{Data}

The SCIATRAN radiation transfer model (RTM) (Rozanov et al., 2001) has been implemented for use in satellite limb, nadir, and lunar/solar occultation retrievals of atmospheric trace gases and aerosols in the UV, visible, and near-IR spectral regions. This RTM code is an extension of the GOMETRAN RTM (Rozanov et al., 1997), and includes an itera- tive spherical approximation of the atmosphere, which is, in particular, required for limb-scatter retrievals.

SCIATRAN also includes an adjustable retrieval code and empirical treatment of clouds as a layer (Rozanov et al., 2005; Rozanov and Kokhanovsky, 2008). It has been successfully employed to retrieve vertical profiles of different chemical species from the measurements performed by the SCIAMACHY instrument (Rozanov et al., 2005, 2007; Bracher et al., 2005; von Savigny et al., 2005; Butz et al., 2006). The version used in this work, SCIATRAN 3.1, is specially designed for ozone retrievals. The user can set different values for different physical and satellite geometry parameters at the initialization step. The forward mode simulates radiances, to be used in retrieval mode later, to retrieve the ozone profiles by applying the optimal estimation method (OEM) or other inversion methods with regularization. By setting different parameters in the initialization stage, the corresponding ozone profiles retrieved from simulations can be compared with each other. This allows for the exact definition of relative errors in the ozone profiles for a given deviation of the parameter settings. The SCIATRAN model is run in the forward calculation in an approximate spherical mode. For this purpose the combined differential-integral (CDI) approach has been used (Rozanov et al., 2001).

Solar radiation passing through the atmosphere may be single and multiply scattered. Therefore the CDI takes the contribution of both scattering processes into account. The single scattering of the incoming solar radiation in the atmosphere is treated fully spherically. For the multiple-scattering part an approximation for each point along the line of sight is calculated. The approximation for different geometries can be solved with the pseudo-spherical radiative transfer equation (Siewert, 2008; Rozanov and Kokhanovsky, 2006). The SCIATRAN radiative transfer code has been compared with other radiative transfer models (Kurosu et al., 1997; Loughman et al., 2004; Hendrick et al., 2006; Wagner et al., 2007), showing generally good agreement. In the study performed by Loughman et al. (2004) of several models the agreement in simulated radiance between the model pairs were within a precision of $2-4 \%$ below $30 \mathrm{~km}$ and diverge up to $7 \%$ for higher altitudes. A description of the forward model calculations with SCIATRAN for cloudy/cloud-free scenarios and a corresponding cloud-related error budget in the SCIAMACHY limb ozone retrieval can be found in Sonkaew et al. (2009).

To retrieve ozone profiles, normalized limb radiance profiles in the UV and the triplet method (Flittner et al., 2000; von Savigny et al., 2003) in the visible wavelength ranges have been used. Normalized limb radiance profiles in the Chappuis, Hartley, and Huggins bands are used in a simultaneous retrieval to obtain the ozone number density and extend the ozone profile to altitudes up to $80 \mathrm{~km}$. Only selected wavelengths are used from the Hartley band in order to avoid the dayglow emission and Fraunhofer lines (Sonkaew et al., 2009). In the optical wavelength range the triplet method has 

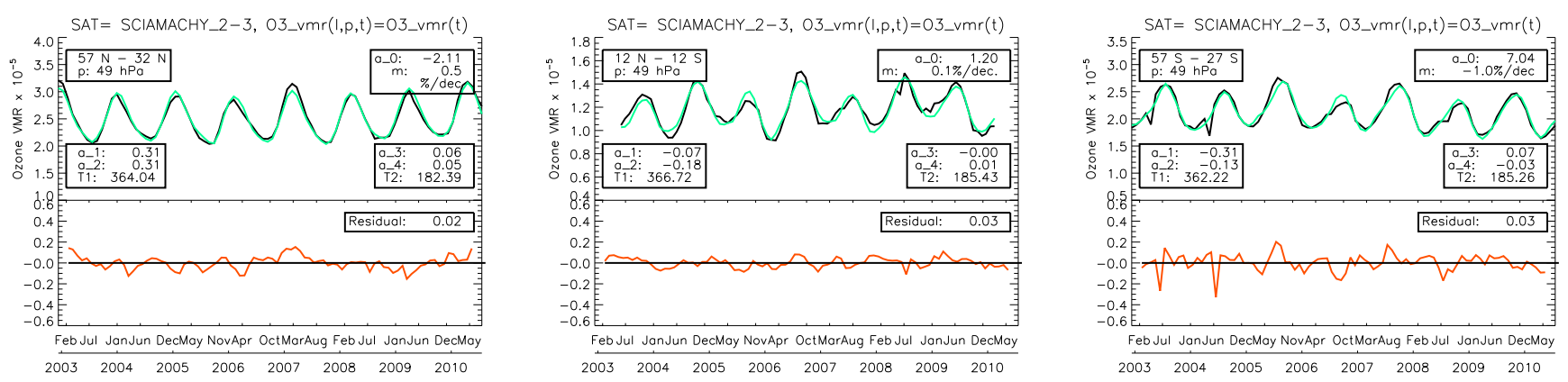

Fig. 1. SCIAMACHY limb ozone time series at $49 \mathrm{hPa}$ at three different latitude bands (black solid line) with corresponding fitted curves (green solid line) and residuals (orange solid line). The fit has been obtained from a multivariate linear regression that includes seasonal, QBO, solar cycle, and linear trend terms. The residual is calculated as the fraction of total of residuum (absolute) to the average of the original data.
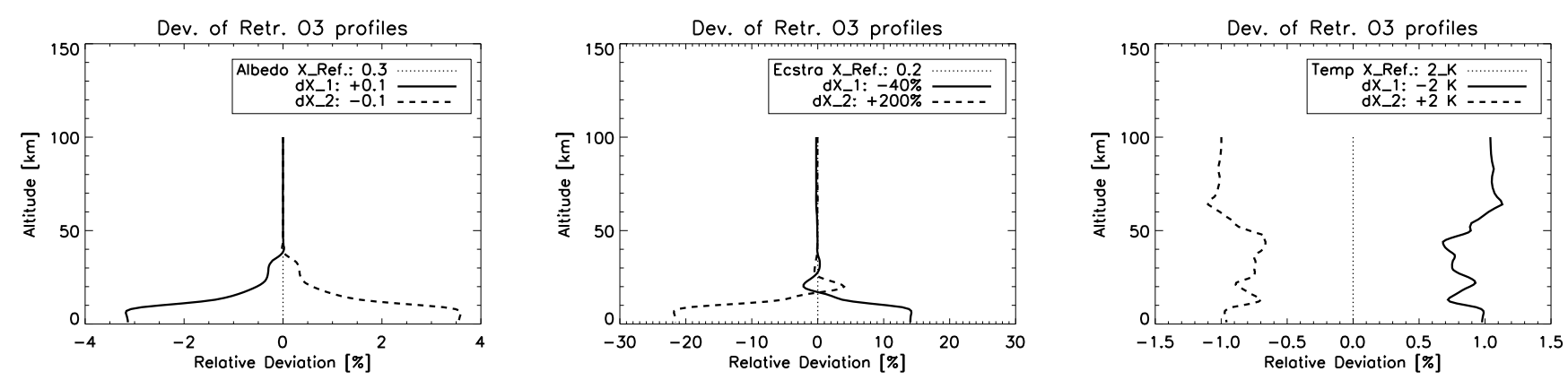

Fig. 2. Percentage error of SCIAMACHY limb ozone profiles simulated for positive and negative change in parameter settings as indicated relative to the reference case $\left(X_{\mathrm{Ref}}\right)$ in order to investigate the sensitivity toward the direction of the selected parameter deviations. Examples for (a) albedo, (b) aerosol, and (c) temperature errors are shown here. The viewing geometry is taken from SCIAMACHY orbit 33566 (1 August 2008) at geolocation of $70^{\circ} \mathrm{N}$ and $165^{\circ} \mathrm{E}$, with solar azimuth angle (SAA) of $29^{\circ}$ and solar zenith angle of (SZA) $52^{\circ}$.

been used. The strong absorption in the Chappuis band with its maximum at $602 \mathrm{~nm}$ and two weaker absorptions at the wings at 525 and $675 \mathrm{~nm}$ are combined together to build the Chappuis triplet. The triplet is calculated as follows:

$I_{\text {Chap }}(\mathrm{TH})=\ln \frac{I\left(\lambda_{2}, \mathrm{TH}\right)}{\sqrt{I\left(\lambda_{1}, \mathrm{TH}\right) I\left(\lambda_{3}, \mathrm{TH}\right)}}$,

with $I_{\text {Chap }}(\mathrm{TH})$ being the triplet for a given tangent height $\mathrm{TH}$ and corresponding three wavelengths $\lambda_{1}=602 \mathrm{~nm}, \lambda_{1}=$ $525 \mathrm{~nm}$, and $\lambda_{3}=675 \mathrm{~nm}$.

The SCIATRAN code uses temperature $(T)$ and pressure ( $p$ ) profiles as input for the retrieval of ozone number density. For the ozone profile retrieval the ECMWF (European Centre for Medium-Range Weather Forecasts) operational analysis $p$ and $T$ profiles are used for the day, time, and location of each individual SCIAMACHY measurement.

\section{Error characterization}

Possible impacts of parameter uncertainties on the retrieved ozone profiles are investigated as follows. In the first step the ozone profile retrieved from SCIATRAN simulated radiances for a given reference parameter is compared with a set of profiles retrieved with different values of the same parameter (von Savigny et al., 2005a). For example, in order to calculate the possible impact of surface albedo on the retrieved ozone profiles, a reference scenario with constant albedo of 0.3 is selected. In the second step the retrieval is then run with an albedo value of 0.4 . The relative uncertainties are calculated then as follows:

$\sigma(\mathrm{dAlb}, z)=\frac{\mathrm{O}_{3}(X, z)-\mathrm{O}_{3}(\operatorname{Ref}, z)}{\mathrm{O}_{3}(\operatorname{Ref}, z)}$,

with $\mathrm{O}_{3}(\operatorname{Ref}, z)$ and $\mathrm{O}_{3}(X, z)$ being the ozone number density retrieved at altitude $z$ with fixed albedo value Ref and variable albedo value of $X$, respectively. In the example with albedo value of $X=0.4$, an uncertainty in retrieved ozone number density with albedo parameter deviation of $\mathrm{dAlb}=X-\operatorname{Ref}=+0.1$ can be calculated and denoted as $\sigma(\mathrm{dAlb})=\sigma(\mathrm{dAlb}=+0.1)$. The deviation of the ozone profile for a given parameter value from the ozone profile with the reference value defines the parameter error or uncertainty for a given parameter change. This approach has been applied for different parameters that affect ozone retrievals, e.g. albedo, stratospheric aerosol, temperature, pressure, tangent 


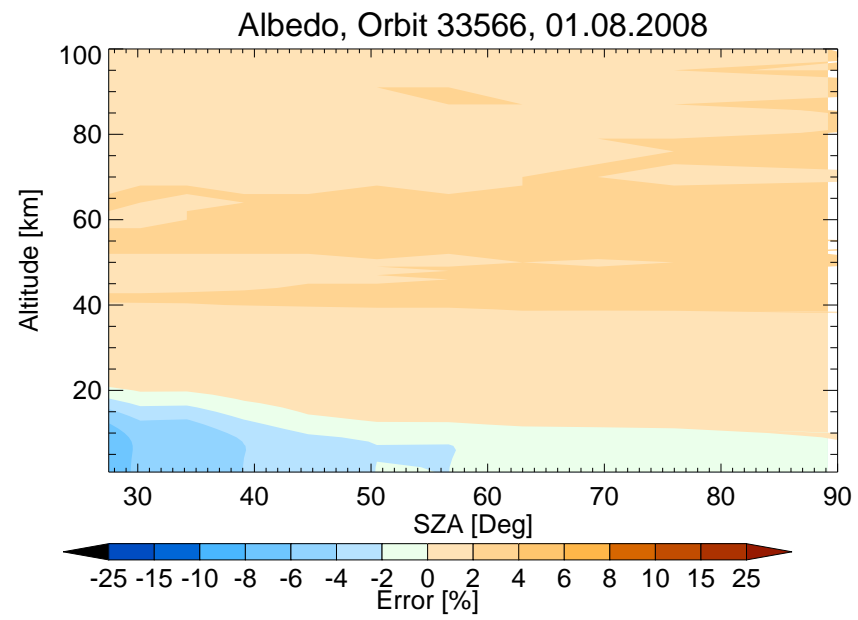

Fig. 3. Contour plot of the ozone retrieval error as a function of solar zenith angle and altitude for an albedo perturbation of 0.1 and for the orbit 33566 .

height, signal-to-noise ratio, and choice of ozone cross section. The error calculation for a given parameter has been done for different SCIAMACHY limb observation geometries. In the following we will present the error contribution of each parameter in a case study using SCIAMACHY observation geometries in orbit 33566 (1 August 2008) in the Northern Hemisphere high latitudes $\left(70^{\circ} \mathrm{N}\right)$ with solar azimuth angle (SAA) of $29^{\circ}$ and solar zenith angle (SZA) of $52^{\circ}$. Note that the sensitivity analysis has been performed for five days (18 April 2008, 1 August 2008, 12 Augst 2008, 3 October 2008, and 14 October 2008), which cover three seasons. In section 4 we will present the total errors as the average calculated from different geometries and days for the year 2008 sorted into latitude bins.

\subsection{Albedo}

For the impact of albedo (Matthews, 1983) on the retrieval the calculation has been run with a value of 0.3 as the reference. Uncertainties in albedo values from several studies can range between 0.05 and 0.25 depending on SZA and surface structure (Barker and Davies, 1989). Cloudy scene and background aerosol can increase these values significantly. A deviation of 0.1 in the albedo is assumed to be a conservative but realistic estimation of error in the albedo value in the retrieval. The percentage errors for the comparison of the ozone profile with albedo changes of \pm 0.1 are shown in Fig. 2a as an example for a single ozone profile retrieval. The result shows that the deviation is symmetrical in both lower and higher albedos, and therefore the direction of the forcing does not affect the absolute value of the error. The main effect of overestimating the albedo is the underestimation of the retrieved ozone values in the altitude range $0-40 \mathrm{~km}$. As the scattering altitude increases at lower UV wavelengths due to increased $\mathrm{O}_{3}$ absorption, the albedo effect vanishes in the
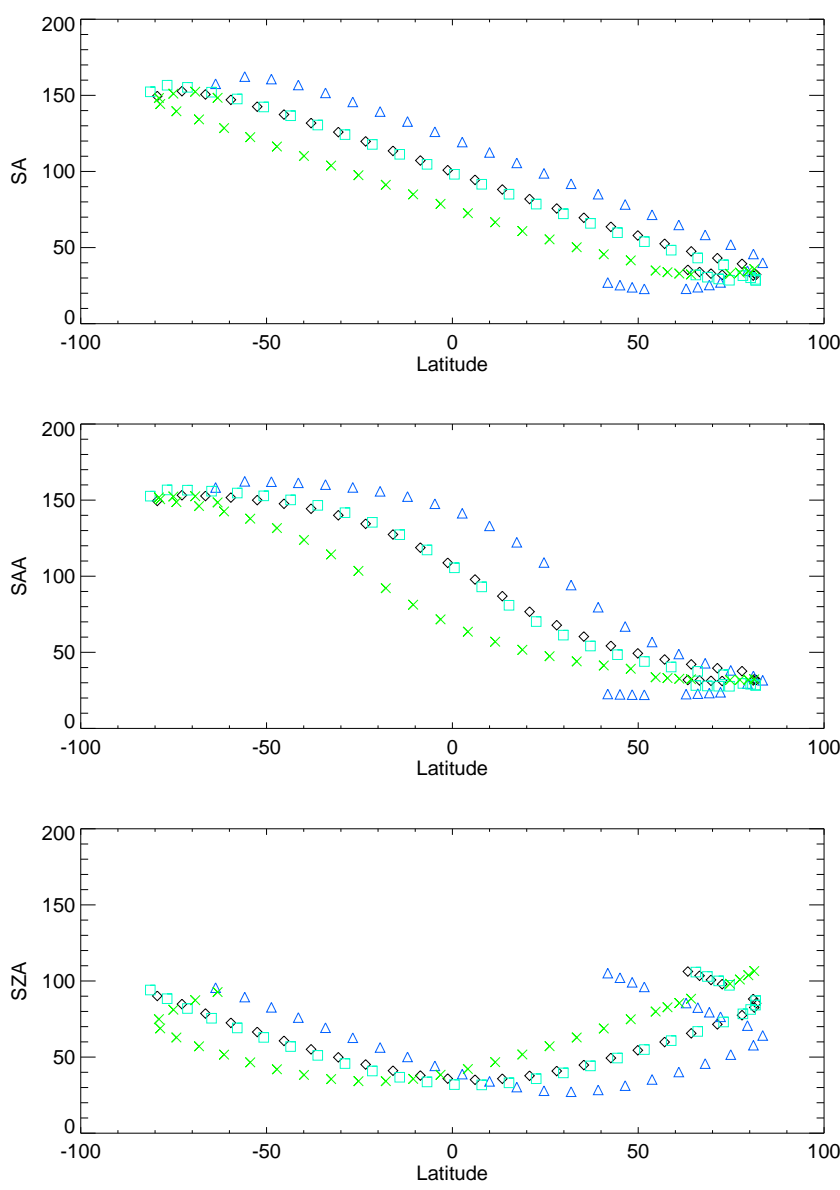

Fig. 4. Latitudinal distribution of the three geometrical parameters scattering angle (SA, top panel), solar azimuth angle (SAA, middle panel), and solar zenith angle (SZA, bottom panel) for the 21th of March (black diamonds), 21st of June (blue triangles), 23th of September (blue squares), and 21th of December (green crosses).

Hartley bands that mainly contribute to the retrieval in the upper stratosphere and mesosphere.

A contour plot of the ozone retrieval error for an error in the surface albedo of 0.1 as a function of SZA and altitude is shown in Fig. 3 for one orbit. Negative values occur at small SZA - i.e. low latitudes - in the lower atmosphere (0$20 \mathrm{~km}$ ). For larger SZA - corresponding to mid-latitudes and polar regions - the effect of albedo on the ozone retrieval error is smaller. This can be seen in Fig. 3, particularly at low altitudes. We can conclude that the ozone retrieval error associated with uncertainties in albedo is sensitive to the SZA. For small SZAs the ozone retrieval errors are higher and vice versa. The latitude of the SZA minimum varies throughout the year, and its seasonal dependence is depicted in Fig. 4.

\subsection{Stratospheric aerosol}

SCIATRAN uses the ECSTRA (Extinction Coefficient for STRatospheric Aerosol) climatological profiles in the 

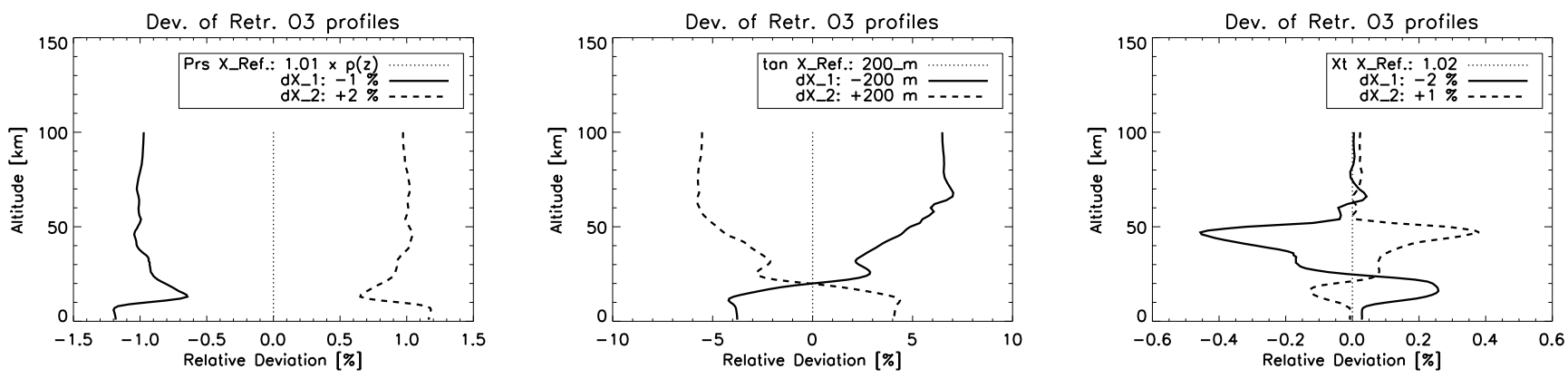

Fig. 5. Similar to Fig. 2 but for the following parameters: (a) pressure, (b) tangent height, and (c) temperature sensitivity of $\mathrm{O}_{3}$ absorption cross section (T-ozone). The viewing geometry is taken from SCIAMACHY orbit 33566 (1 August 2008) at geolocation of $70^{\circ} \mathrm{N}$ and $165^{\circ} \mathrm{E}$, with SAA of $29^{\circ}$ and SZA of $52^{\circ}$.
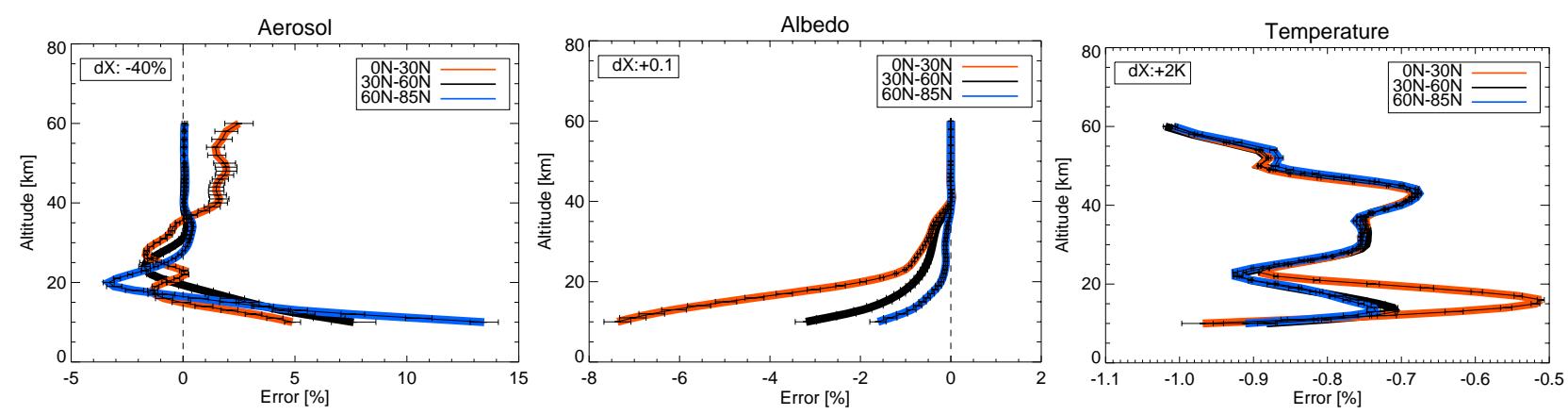

Fig. 6. Average error profiles from 10 to $60 \mathrm{~km}$ for three different latitude bands (Northern Hemisphere) - i.e. tropics (red line), mid-latitudes (black line), and polar region (blue line) - and for the parameters (a) aerosol, (b) albedo, and (c) temperature.

retrieval (Fussen and Bingen, 1999). The reference value for stratospheric aerosol optical depth is set to $0.2 \times 10^{-2}$. Realistic values for uncertainties in stratospheric aerosol optical depth are thought to be of the order of $16-60 \%$ with respect to stratospheric background conditions (Remer et al., 2002). For this work, in agreement with the comparison of SCIAMACHY and SAGE aerosol profiles (Ernst et al., 2012), we selected a mean value of $40 \%$ uncertainty for the aerosol extinction. It should be kept in mind that the errors in aerosol profile can be minimized in the future by incorporating the results from aerosol retrieval in the ozone retrieval. In our case the errors presented here are the upper boundary for possible realistic aerosol uncertainties. An example is shown in Fig. 2b, where the aerosol optical depth is reduced by $40 \%$ (solid line) and increased by $100 \%$ (dashed line) from the reference value. Ozone is overestimated for low aerosol optical depth. At $10 \mathrm{~km}$ the overestimation is of the order of $15 \%$ and decreases fast for higher altitudes, and can be neglected for altitudes above $30 \mathrm{~km}$.

The ozone retrieval errors associated with errors in the stratospheric aerosol data exhibit a different latitudinal dependence as compared to the errors due to uncertainties in surface albedo. The aerosol-induced error depends on the scattering phase function and hence on the scattering angle. For this reason the three angles SZA, SAA, and SA (scat- tering angle) of the SCIAMACHY limb-scatter observations are shown as a function of latitude for four days in different seasons (22 March, 21 June, 23 September, and 21 December 2007 in Fig. 4. The scattering angle depends on SZA and SAA in the following way: $\cos (\mathrm{SA})=\sin (\mathrm{SZA}) \cdot \cos (\mathrm{SAA})$. Small SAs lead to higher impact of aerosol on the ozone retrieval and hence to larger errors.

\subsection{Temperature}

Since temperature profiles are not retrieved directly from SCIAMACHY observations, ECMWF analysis temperatures are used in the retrieval. Temperature uncertainties in the ECMWF data are assumed to be of the order of $1-2 \mathrm{~K}$ from comparisons between IASI, NCEP, and ECMWF for altitudes below $35 \mathrm{~km}$ (Nowlan, 2006; Masiello et al., 2011; Boccara et al., 2008). In order to evaluate the possible influence of temperature on ozone, temperature has been increased and decreased by a value of $2 \mathrm{~K}$. The relative errors in retrieved ozone due to uncertainties in temperature of $\pm 2 \mathrm{~K}$ are shown in Fig. 2c. Higher (lower) temperature leads to underestimation (overestimation) of ozone values. The errors are lower than $1 \%$ for all altitudes. 
Table 1. SCIAMACHY retrieval wavelengths and their corresponding signal-to-noise ratio (SNR).

\begin{tabular}{llllllllllll}
\hline$\lambda[\mathrm{nm}]$ & 264 & 267.5 & 273.5 & 283 & 286 & 288 & 290 & 305 & 525 & 590 & 675 \\
\hline $\operatorname{SNR}(\lambda)$ & 15 & 15 & 15 & 30 & 30 & 30 & 30 & 50 & 140 & 140 & 140 \\
\hline
\end{tabular}
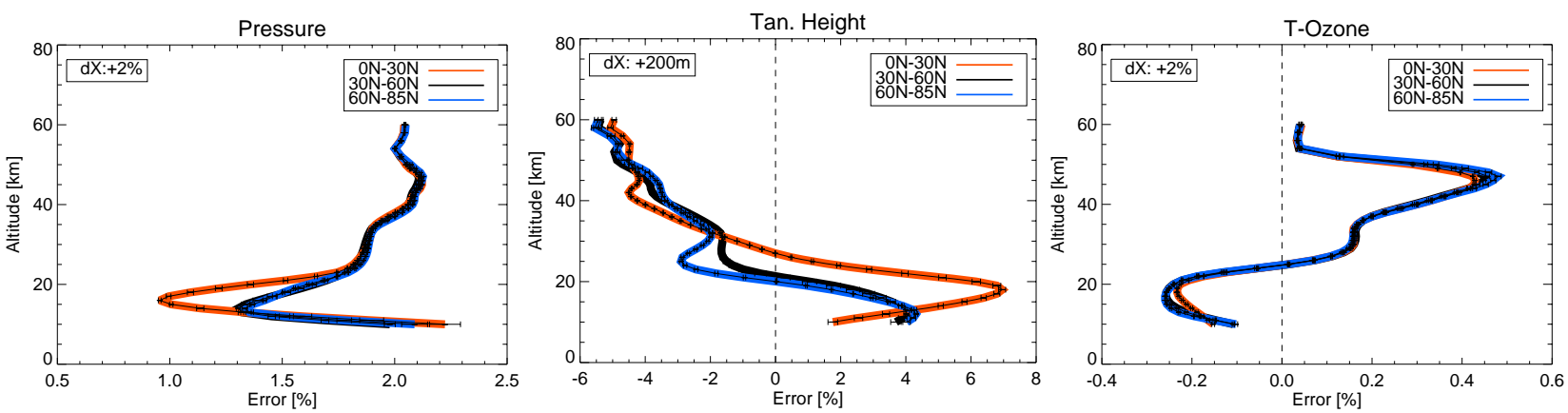

Fig. 7. Average error profiles from 10 to $60 \mathrm{~km}$ for three different latitude bands (Northern Hemisphere) - i.e. tropics (red line), mid-latitudes (black line), and polar region (blue line) - and for the parameters (a) pressure, (b) tangent height, and (c) temperature dependence of the ozone absorption cross section.
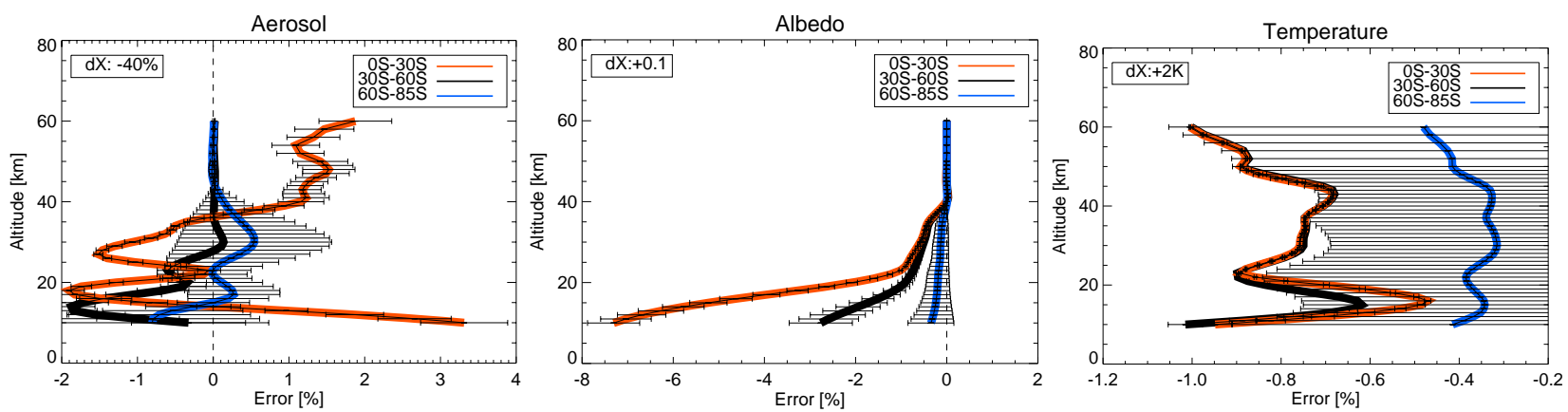

Fig. 8. Average error profiles from 10 to $60 \mathrm{~km}$ for three different latitude bands (Southern Hemisphere) - i.e. tropics (red line), mid-latitudes (black line), and polar region (blue line) - and for the parameters (a) aerosol, (b) albedo, and (c) temperature.
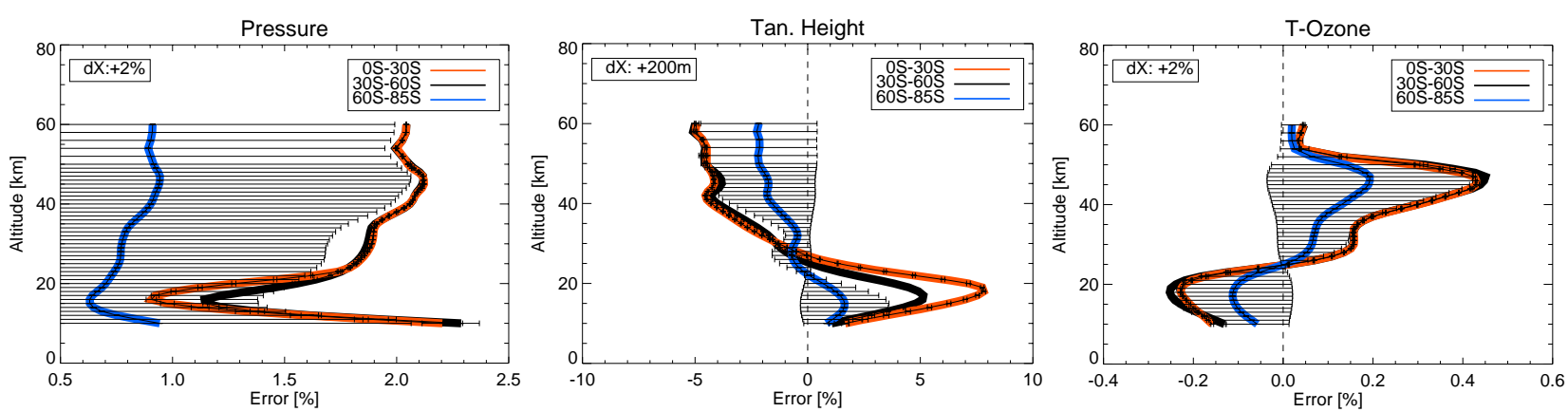

Fig. 9. Average error profiles from 10 to $60 \mathrm{~km}$ for three different latitude bands (Southern Hemisphere) - i.e. tropics (red line), mid-latitudes (black line) and polar region (blue line) - and for the parameters (a) pressure, (b) tangent height, and (c) temperature dependence of the ozone absorption cross section. 
Table 2. Average errors in percent in retrieved ozone for each parameter for the tropics: $\left[0^{\circ}-30^{\circ}\right]$. The uncertainties for each parameter are +0.1 for albedo, $-40 \%$ for aerosol extinction coefficient scaling, $+2 \%$ for pressure, $+2 \mathrm{~K}$ for temperature, $+200 \mathrm{~m}$ for tangent height, $+2 \%$ for air density. Comparison between gpp (GOME) - V2 (SCIA) experimental cross-section values, clouds, and predefined SNR vector from Table 1 .

\begin{tabular}{|c|c|c|c|c|c|c|c|c|c|c|c|c|}
\hline Parameter & Hem. & $10 \mathrm{~km}$ & $15 \mathrm{~km}$ & $20 \mathrm{~km}$ & $25 \mathrm{~km}$ & $30 \mathrm{~km}$ & $35 \mathrm{~km}$ & $40 \mathrm{~km}$ & $45 \mathrm{~km}$ & $50 \mathrm{~km}$ & $55 \mathrm{~km}$ & $60 \mathrm{~km}$ \\
\hline Albedo & $\mathrm{NH}$ & -7.4 & -6.6 & -5.0 & -1.9 & -0.8 & -0.5 & -0.4 & -0.1 & -0.1 & -0.1 & -0.1 \\
\hline Albedo & $\mathrm{SH}$ & -7.3 & -6.7 & -5.2 & -2.1 & -0.8 & -0.6 & -0.4 & -0.1 & -0.1 & -0.1 & -0.1 \\
\hline Aerosol & $\mathrm{NH}$ & 4.9 & 3.1 & -0.1 & -0.8 & -1.1 & -1.2 & -0.2 & 1.6 & 1.5 & 1.9 & 2.5 \\
\hline Aerosol & $\mathrm{SH}$ & 3.3 & 1.9 & -0.8 & -1.3 & -1.0 & -1.1 & -0.4 & 1.2 & 1.3 & 1.4 & 1.9 \\
\hline Pressure & $\mathrm{NH}$ & 2.2 & 1.6 & 1.0 & 1.4 & 1.8 & 1.9 & 1.9 & 2.1 & 2.1 & 2.0 & 2.0 \\
\hline Pressure & $\mathrm{SH}$ & 2.2 & 1.6 & 1.0 & 1.3 & 1.8 & 1.9 & 1.9 & 2.1 & 2.1 & 2.0 & 2.0 \\
\hline Temperature & $\mathrm{NH}$ & -1.0 & -0.7 & -0.5 & -0.7 & -0.9 & -0.8 & -0.7 & -0.7 & -0.7 & -0.9 & -1.0 \\
\hline Temperature & $\mathrm{SH}$ & -0.9 & -0.7 & -0.5 & -0.7 & -0.9 & -0.8 & -0.7 & -0.7 & -0.7 & -0.9 & -1.0 \\
\hline Tangent Height & $\mathrm{NH}$ & 1.8 & 3.4 & 5.8 & 6.2 & 1.1 & -1.2 & -2.9 & -4.2 & -4.2 & -4.5 & -5.0 \\
\hline Tangent Height & $\mathrm{SH}$ & 1.7 & 3.5 & 6.3 & 7.1 & 1.3 & -1.3 & -3.0 & -4.3 & -4.2 & -4.5 & -4.9 \\
\hline T-ozone & $\mathrm{NH}$ & -0.2 & -0.2 & -0.2 & -0.2 & 0.1 & 0.2 & 0.2 & 0.3 & 0.4 & 0.3 & 0.1 \\
\hline T-ozone & $\mathrm{SH}$ & -0.2 & -0.2 & -0.2 & -0.2 & 0.1 & 0.2 & 0.2 & 0.3 & 0.4 & 0.3 & 0.1 \\
\hline Cross Section & $\mathrm{NH}$ & -0.2 & -0.1 & -0.1 & 0.1 & 0.2 & 0.5 & 0.4 & -0.1 & 0.4 & 0.1 & 0.2 \\
\hline Cross Section & $\mathrm{SH}$ & -0.2 & -0.1 & -0.1 & 0.1 & 0.2 & 0.4 & 0.5 & -0.1 & 0.4 & 0.1 & 0.2 \\
\hline Clouds & - & -3.0 & -2.8 & -2.5 & -2.4 & -2.0 & -1.5 & -1.0 & -0.5 & -0.1 & -0.1 & -0.1 \\
\hline APSD & $\mathrm{NH}$ & 43 & 30 & 19 & 14 & 14 & 14 & 12 & 11 & 9.8 & 11 & 10 \\
\hline APSD & $\mathrm{SH}$ & 47 & 34 & 19 & 14 & 14 & 14 & 12 & 10 & 11 & 12 & 10 \\
\hline
\end{tabular}

\subsection{Pressure}

In order to evaluate the possible influence of uncertainties in pressure on the ozone profile retrieval, the pressure profile is multiplied by a scaling factor. An uncertainty of $2 \%$ in the ECMWF data is assumed, which is in agreement with 2-5\% difference for altitudes below $60 \mathrm{~km}$ between MAESTRO, NCEP, and ECMWF (Nowlan, 2006; Masiello et al., 2011). An example of the pressure error profile is shown in Fig. 5a for two different scaling factors. A decrease of $1 \%$ (solid line) and increase of $1 \%$ (dashed line) is shown relative to the reference case of 1.01 scaling factor. The main effect of an increase in pressure on the retrieval is the overestimation of ozone concentration. In this example an uncertainty in pressure of the order of $\pm 1 \%$ contributes a $1 \%$ error to the retrieved ozone for most of the atmosphere.

\subsection{Tangent height}

In order to investigate the effect of possible errors in the tangent height registration, the forward model is run with a different tangent height grid. Positive tangent height errors correspond to the case when the assumed tangent heights are larger than the actual ones, which implies that the altitude grid is shifted upwards relative to the prior reference tangent height position. The uncertainty in the tangent height registration is about $200 \mathrm{~m}$ (von Savigny et al., 2009). Figure $5 \mathrm{~b}$ shows the errors in retrieved ozone concentration for a tangent height error of $\pm 200 \mathrm{~m}$. For altitudes above $20 \mathrm{~km}$ the retrieved ozone concentrations are underestimated if the actual tangent heights are larger than the ones used for the retrieval. The corresponding error values can increase up to $6 \%$ for the stratosphere and mesosphere.

\subsection{A posteriori standard deviation (APSD)}

Radiance measurement errors which lead to random errors in the retrieval are also discussed in this part of the work. The square roots of the diagonal elements of the a posteriori covariance matrix $\mathbf{S}^{*}$ denoted as the a posteriori standard deviations (APSD) are presented here. The a priori covariance matrix $\mathbf{S}_{\mathrm{a}}$, with diagonal elements $\left(\mathbf{S}_{\mathrm{a}_{i i}}=4\right)$ and exponentially decaying off-diagonal elements with a correlation radius of $3.3 \mathrm{~km}$, is set in the retrieval with the corresponding measurement covariance matrix $\mathbf{S}_{y}$. Smoothing is done using the Tikhonov regularization scheme. The diagonal elements of the $\mathbf{S}_{y}$ are constructed using the SNR (signal-to-noise ratio) vector (Table 1). For a given wavelength and different tangent heights the same SNR value is used. This assumption is justified because the SNR of the normalized limb radiance profiles at a given wavelength is mainly determined by the SNR of the radiance at the reference tangent height. For example, at the wavelength $\lambda=283 \mathrm{~nm}$ the corresponding diagonal elements of $\mathbf{S}_{y}$ have the values $\mathbf{S}_{y_{i i}}\left(h_{i}\right)=\sigma^{2}=1 / 900$.

\subsection{Temperature sensitivity of $\mathrm{O}_{3}$ absorption cross section}

By changing the temperature or pressure it was possible to evaluate the impact of air density changes on ozone (see Sects. 3.3 and 3.4). In order to evaluate the impact of temperature on the ozone absorption cross section, the temperature 
Table 3. Average errors in percent for the mid-latitudes, $\left[30^{\circ}-60^{\circ}\right]$, for the same parameters as in Table 2.

\begin{tabular}{lrrrrrrrrrrrr}
\hline Parameter & Hem. & $10 \mathrm{~km}$ & $15 \mathrm{~km}$ & $20 \mathrm{~km}$ & $25 \mathrm{~km}$ & $30 \mathrm{~km}$ & $35 \mathrm{~km}$ & $40 \mathrm{~km}$ & $45 \mathrm{~km}$ & $50 \mathrm{~km}$ & $55 \mathrm{~km}$ & $60 \mathrm{~km}$ \\
\hline Albedo & $\mathrm{NH}$ & -3.2 & -2.3 & -1.5 & -0.8 & -0.5 & -0.4 & -0.2 & 0.1 & 0.1 & -0.1 & 0.1 \\
Albedo & $\mathrm{SH}$ & -2.8 & -2.4 & -1.7 & -0.9 & -0.7 & -0.5 & -0.4 & 0.1 & 0.1 & -0.1 & 0.1 \\
Aerosol & $\mathrm{NH}$ & 7.6 & 5.4 & 2.9 & -0.4 & -1.6 & -0.2 & 0.2 & 0.1 & 0.1 & 0.1 & 0.1 \\
Aerosol & $\mathrm{SH}$ & -0.3 & -1.5 & -1.7 & -0.3 & -0.4 & 0.1 & 0.1 & 0.1 & 0.1 & 0.1 & 0.1 \\
Pressure & $\mathrm{NH}$ & 2.0 & 1.5 & 1.3 & 1.6 & 1.8 & 1.9 & 1.9 & 2.1 & 2.1 & 2.1 & 2.0 \\
Pressure & $\mathrm{SH}$ & 2.3 & 1.6 & 1.1 & 1.6 & 1.8 & 1.9 & 1.9 & 2.1 & 2.1 & 2.1 & 2.0 \\
Temperature & $\mathrm{NH}$ & -0.9 & -0.7 & -0.7 & -0.9 & -0.9 & -0.7 & -0.7 & -0.7 & -0.7 & -0.9 & -1.0 \\
Temperature & $\mathrm{SH}$ & -1.0 & -0.8 & -0.6 & -0.8 & -0.8 & -0.7 & -0.7 & -0.7 & -0.7 & -0.9 & -1.0 \\
Tangent Height & $\mathrm{NH}$ & 3.7 & 4.0 & 3.6 & 1.0 & -1.5 & -1.6 & -2.2 & -3.5 & -3.9 & -4.9 & -5.4 \\
Tangent Height & $\mathrm{SH}$ & 1.1 & 2.8 & 4.8 & 3.8 & 0.1 & -1.4 & -2.5 & -4.0 & -3.8 & -4.6 & -5.0 \\
T-ozone & $\mathrm{NH}$ & -0.1 & -0.2 & -0.2 & -0.2 & 0.1 & 0.2 & 0.2 & 0.3 & 0.4 & 0.3 & 0.1 \\
T-ozone & $\mathrm{SH}$ & -0.1 & -0.2 & -0.2 & -0.2 & 0.1 & 0.2 & 0.2 & 0.3 & 0.4 & 0.3 & 0.1 \\
Cross Section & $\mathrm{NH}$ & -0.1 & -0.1 & 0.1 & 0.1 & 0.3 & 0.5 & 0.4 & -0.1 & 0.4 & 0.1 & 0.2 \\
Cross Section & $\mathrm{SH}$ & -0.1 & -0.1 & 0.1 & 0.1 & 0.3 & 0.5 & 0.5 & -0.1 & 0.4 & 0.1 & 0.2 \\
Clouds & - & -3.0 & -2.8 & -2.5 & -2.4 & -2.0 & -1.5 & -1.0 & -0.5 & -0.1 & -0.1 & -0.1 \\
APSD & $\mathrm{NH}$ & 26 & 18 & 16 & 13 & 15 & 15 & 12 & 11 & 9.8 & 11 & 10 \\
APSD & $\mathrm{SH}$ & 33 & 23 & 17 & 14 & 14 & 14 & 12 & 10 & 11 & 12 & 10 \\
\hline
\end{tabular}

and pressure are changed in such a way that the air density does not change. Since the $\mathrm{O}_{3}$ absorption cross section depends only on temperature, and not on pressure, this is a suitable way to investigate the effect of the temperature sensitivity of the absorption cross section on the ozone profile retrievals (T-ozone). Any deviation in the ozone concentration is then a consequence of the temperature sensitivity of the ozone cross section alone. The error profile due to a variation of $p$ and $T$ is shown in Fig. 5c. The temperature change of $\approx 2 \mathrm{~K}$ at constant air density leads to very small errors of up to $0.4 \%$, compared to the direct temperature effect (1\%) as shown in Fig. 2c.

\subsection{Ozone cross section}

Different laboratory measurements of the ozone absorption cross sections are available. The Global Ozone Monitoring Experiment (GOME) absorption cross sections (Burrows et al., 1998) and the SCIAMACHY absorption cross-section database (Bogumil et al., 2003) are used to estimate the uncertainties. The ozone cross-section error is here defined as the percentage difference in the retrieved profiles using these two ozone cross sections. The differences are lower than $0.5 \%$ for the entire atmosphere.

\subsection{Impact of tropospheric clouds}

Sonkaew et al. (2009) investigated the impact of tropospheric clouds on the ozone profile retrievals assuming clouds in the forward model and performing the retrieval in a cloud-free atmosphere. One example of their simulation, the error in the presence of clouds with a vertical extent of 4 to $7 \mathrm{~km}$ and optical thickness of $\tau=10$, is included in our error budget analysis. The Sonkaew et al. (2009) result shows a slightly higher sensitivity towards larger SZAs for a constant SAA. For summer conditions at $10 \mathrm{~km}$ the error is of the order of 3 (tropics) and 5.5\% (polar latitudes), and decreases for higher altitudes.

\section{Total}

Based on the error estimation for each individual parameter as a function of SCIAMACHY observation geometry, a total error budget can be established for the SCIAMACHY limb ozone profile retrieval.

The following latitude bands with different SZAs have been selected for the error estimation: tropics $\left[0-30^{\circ}\right]$, midlatitudes $\left[30-60^{\circ}\right]$, and polar latitudes $\left[60-85^{\circ}\right]$. The results of these calculations are summarized in Tables 2-4. In Figs. 6-9 the corresponding average error profiles are shown for the following parameters: aerosol, albedo, temperature, pressure, tangent height, and a posteriori standard deviation for both hemispheres. The calculation has been performed for 5 different days of the year 2008 consisting of 10 orbits, with 204 profiles for the Northern Hemisphere and 137 profiles for the Southern Hemisphere. The numbers in the Tables 2-4 are mean uncertainties/errors $\sigma_{\mathrm{m}}$ in percent for each parameter (rows) and selected altitudes from 10 to $60 \mathrm{~km}$ averaged over $5 \mathrm{~km}$ altitude intervals (columns). The tables indicate that the ozone retrievals errors caused by most of the error sources do not exhibit strong interhemispheric differences. The only exception is stratospheric aerosols, whose effect on the ozone retrievals is significantly larger in the Northern Hemisphere at mid-latitudes. This is related to the latitudinal variation of the SCIAMACHY limb observation geometry, which is associated with scattering angles lower than about $90^{\circ}$ in the Northern Hemisphere, and scattering angles larger 

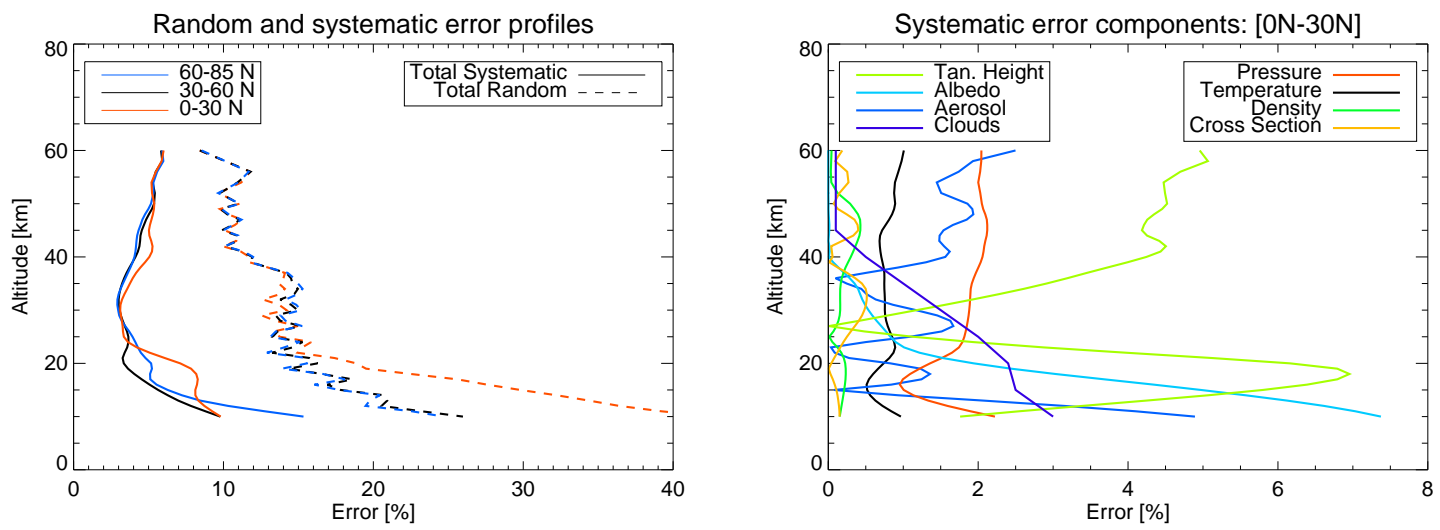

Fig. 10. (a) Total systematic and random error profiles for three latitude bands of the study case. (b) Systematic error components for the tropics in the Northern Hemisphere.

Table 4. Average errors in [\%] for the polar latitudes, $\left[60^{\circ}-85^{\circ} \mathrm{N}\right]$, for the same parameters as in Table 2.

\begin{tabular}{lrrrrrrrrrrrr}
\hline Parameter & Hem. & $10 \mathrm{~km}$ & $15 \mathrm{~km}$ & $20 \mathrm{~km}$ & $25 \mathrm{~km}$ & $30 \mathrm{~km}$ & $35 \mathrm{~km}$ & $40 \mathrm{~km}$ & $45 \mathrm{~km}$ & $50 \mathrm{~km}$ & $55 \mathrm{~km}$ & $60 \mathrm{~km}$ \\
\hline Albedo & $\mathrm{NH}$ & -1.6 & -1.1 & -0.6 & -0.2 & -0.1 & -0.1 & -0.1 & 0.1 & 0.1 & -0.1 & -0.1 \\
Albedo & $\mathrm{SH}$ & -0.3 & -0.3 & -0.2 & -0.2 & -0.2 & -0.1 & -0.1 & 0.1 & 0.1 & -0.1 & -0.1 \\
Aerosol & $\mathrm{NH}$ & 13.5 & 7.6 & 2.1 & -3.3 & -0.8 & 0.3 & 0.4 & 0.1 & 0.1 & 0.1 & 0.1 \\
Aerosol & $\mathrm{SH}$ & -0.8 & -0.7 & 0.1 & 0.1 & 0.1 & 0.5 & 0.4 & 0.1 & 0.1 & -0.1 & -0.1 \\
Pressure & $\mathrm{NH}$ & 2.1 & 1.5 & 1.4 & 1.6 & 1.8 & 1.9 & 1.9 & 2.1 & 2.1 & 2.1 & 2.1 \\
Pressure & $\mathrm{SH}$ & 0.9 & 0.8 & 0.6 & 0.7 & 0.8 & 0.8 & 0.8 & 0.9 & 0.9 & 0.9 & 0.9 \\
Temperature & $\mathrm{NH}$ & -0.9 & -0.8 & -0.8 & -0.9 & -0.9 & -0.8 & -0.8 & -0.7 & -0.7 & -0.9 & -0.9 \\
Temperature & $\mathrm{SH}$ & -0.4 & -0.4 & -0.3 & -0.4 & -0.4 & -0.3 & -0.3 & -0.3 & -0.3 & -0.4 & -0.4 \\
Tangent Height & $\mathrm{NH}$ & 4.0 & 4.3 & 3.5 & 0.1 & -2.9 & -2.1 & -2.5 & -3.4 & -3.7 & -4.6 & -4.6 \\
Tangent Height & $\mathrm{SH}$ & 0.8 & 1.4 & 1.6 & 0.7 & -0.6 & -0.6 & -0.7 & -1.6 & -1.7 & -2.2 & -2.2 \\
T-ozone & $\mathrm{NH}$ & -0.1 & -0.2 & -0.3 & -0.2 & 0.1 & 0.2 & 0.2 & 0.3 & 0.5 & 0.3 & 0.3 \\
T-ozone & $\mathrm{SH}$ & -0.1 & -0.1 & -0.1 & -0.1 & 0.1 & 0.1 & 0.1 & 0.1 & 0.2 & 0.1 & 0.1 \\
Cross Section & $\mathrm{NH}$ & -0.1 & 0.1 & 0.1 & 0.1 & 0.1 & 0.2 & 0.2 & -0.1 & 0.4 & 0.1 & 0.1 \\
Clouds & - & -5.5 & -4.5 & -3.5 & -1.5 & 0.5 & 0.5 & 0.5 & 0.1 & 0.1 & 0.1 & 0.1 \\
APSD & $\mathrm{NH}$ & 25 & 18 & 16 & 13 & 15 & 15 & 12 & 11 & 9.9 & 11 & 10 \\
APSD & $\mathrm{SH}$ & 24 & 19 & 17 & 15 & 13 & 15 & 14 & 11 & 9 & 11 & 8 \\
\hline
\end{tabular}

than about $90^{\circ}$ in the Southern Hemisphere (Fig. 4). This can be observed for the northern polar mid-latitude region. For the Southern Hemisphere the SA is lowest in the tropics and mid-latitudes, which leads to larger observed errors in the tropical part of the Southern Hemisphere in comparison to polar regions (Figs. 6a and 8a).

The distinction between systematic and random errors is valuable for validation and intercomparison of ozone profiles with other instruments. In this case the total systematic error could explain the bias, and the total random error determines precision (Rodgers, 1990; von Clarmann, 2006; Cortesi et al., 2007). The total error $\sigma_{\text {tot }}$ can be calculated as follows if the two error components are independent:

$\sigma_{\text {tot }}^{2}=\sigma_{\text {sys }}^{2}+\sigma_{\text {rnd }}^{2}$,

with $\sigma_{\text {sys }}^{2}$ and $\sigma_{\text {rnd }}^{2}$ being the total systematic and total random variances. For dependent error components this formula can be used as the upper limit:

$\sigma_{\text {tot }} \leq\left|\sigma_{\text {sys }}\right|+\left|\sigma_{\text {rnd }}\right|$,

We assume that the ozone retrieval errors due to errors in temperature, pressure, tangent height, and cross sections are systematic, since uncertainties are inherent in every measurement. On the other hand the APSD error is random. Total systematic $\left(\sigma_{\text {sys }}\right)$ and random $\left(\sigma_{\text {rnd }}\right)$ errors are calculated for the three latitude bands and different altitudes (Table 5), and are shown as profiles in Fig. 10a. The total systematic error is calculated using the square root of the sums of the variances from each parameter. The total random error is the APSD in this case. The contributions to the total systematic error come from the aerosol $( \pm 13 \%)$, albedo $( \pm 8 \%)$, tangent height $( \pm 8 \%)$, clouds $( \pm 5 \%)$, cross section $( \pm 1 \%)$, pressure $( \pm 2 \%)$, and temperature $( \pm 1 \%)$. An example of each systematic error component for the tropics in the Northern Hemisphere $\left[0-30^{\circ}\right]$ is shown in Fig. 10b. The maximum 
Table 5. Total error $\pm \sigma_{\text {tot }}$ in [\%] for the three different latitude bands for both hemispheres (NH/SH) separated into total systematic and total random uncertainties for tropics, $0^{\circ}-30^{\circ}$; mid-latitudes, $30^{\circ}-60^{\circ}$; and polar region, $60^{\circ}-85^{\circ}$.

\begin{tabular}{lrrrrrrrrrrr}
\hline Lat. Band & $10 \mathrm{~km}$ & $15 \mathrm{~km}$ & $20 \mathrm{~km}$ & $25 \mathrm{~km}$ & $30 \mathrm{~km}$ & $35 \mathrm{~km}$ & $40 \mathrm{~km}$ & $45 \mathrm{~km}$ & $50 \mathrm{~km}$ & $55 \mathrm{~km}$ & $60 \mathrm{~km}$ \\
\hline Total Systematic & & & & & & & & & & & \\
\hline NH: Tropics & 9 & 8 & 8 & 7 & 3 & 3 & 3 & 5 & 5 & 5 & 6 \\
NH: Midlat. & 9 & 7 & 5 & 3 & 3 & 3 & 3 & 4 & 4 & 5 & 5 \\
NH: Polar & 15 & 10 & 6 & 5 & 3 & 2 & 3 & 4 & 4 & 5 & 5 \\
SH: Tropics & 9 & 8 & 8 & 8 & 3 & 3 & 3 & 4 & 4 & 5 & 5 \\
SH: Midlat. & 4 & 5 & 6 & 4 & 2 & 2 & 3 & 4 & 4 & 5 & 5 \\
SH: Polar & 5 & 5 & 4 & 3 & 1 & 1 & 1 & 1 & 2 & 2 & 2 \\
\hline Total Random & & & & & & & & & & & \\
\hline NH: Tropics & 43 & 30 & 19 & 13 & 14 & 14 & 12 & 10 & 11 & 12 & 10 \\
NH: Midlat. & 26 & 18 & 16 & 13 & 15 & 15 & 12 & 10 & 11 & 11 & 10 \\
NH: Polar & 25 & 18 & 16 & 13 & 15 & 15 & 12 & 11 & 10 & 11 & 10 \\
SH: Tropics & 47 & 34 & 19 & 14 & 14 & 14 & 12 & 10 & 10 & 12 & 10 \\
SH: Midlat. & 33 & 23 & 17 & 14 & 14 & 14 & 12 & 10 & 11 & 12 & 10 \\
SH: Polar & 42 & 26 & 21 & 19 & 20 & 21 & 21 & 15 & 20 & 19 & 18 \\
\hline
\end{tabular}

random error is of the order of $\pm 34 \%$ in the tropics at $15 \mathrm{~km}$, and decreases down to $12 \%$ for higher altitudes in the Northern Hemisphere. The values of the random error component are systematically higher for the Southern Hemisphere.

\section{Discussion}

The sensitivity study presented here shows similar results compared to sensitivity studies performed for SAGE III (Rault and Taha, 2007) and MLS (Froidevaux et al., 2008). In both studies, precision and accuracy have been estimated using a similar method. For SAGE III limb-scatter measurements, the instrument error in stratospheric ozone caused by albedo errors (surface reflectance) has been estimated to be of the order of $3 \%$ for the altitude range of $20-30 \mathrm{~km}$. In the study by Rault and Taha (2007) a surface reflectance change of 0.45 has been used, which can lead to a $13 \%$ error at $15 \mathrm{~km}$. In our study the error is of the order of $6 \%$ for an albedo perturbation of 0.1 in the tropics at $15 \mathrm{~km}$. The same study reveals a $6 \%$ error around $20 \mathrm{~km}$ when the stratospheric aerosol are neglected. Our calculation of $40 \%$ aerosol perturbation relative to the background state leads to a $2.9 \%$ error at $20 \mathrm{~km}$ in northern mid-latitudes, decreasing fast with increasing altitude (see Table 3 ). The third common parameter used for the study is the tangent height. In SAGE III an offset of $350 \mathrm{~m}$ has been used, which leads to errors of the order of $5 \%$ and a peak error value of $12 \%$ at $15 \mathrm{~km}$. Our study reveals an error of $4 \%$ above $30 \mathrm{~km}$ with a peak around $20 \mathrm{~km}$ of the order of $6 \%$ for an offset of $200 \mathrm{~m}$. For temperature the sensitivity study of MLS V 2.2 performed by Froidevaux et al. (2008) can be used. The effect of temperature uncertainties on ozone retrievals in the microwave and UV-visible range may be entirely different, and as such our results cannot be directly compared to the MLS values. The temperature induced error is of the order of $2 \%$ and is consistent with our results. In the same study the impact of radiometric knowledge and spectroscopy have been evaluated as of the order of $2 \%$ in the stratosphere. Stray light and polarization effects can add up to the total error budget as well. Neglecting these additional parameters can lead to underestimation of the total error budget. Polarization is altitude dependent, and due to the normalization scheme used for ozone retrieval, the altitude dependence of polarization and the differential structure of polarization can influence the scattering process. The differential structure in polarization is of the order of 0.1 , which leads to a $1-2 \%$ effect on single scattering.

\section{Conclusions}

The SCIATRAN radiation transfer code has been used in order to determine the sensitivity of ozone profile retrievals from SCIAMACHY limb-scatter measurements to eight parameters known to provide a potentially major contribution to SCIAMACHY limb ozone profile retrieval errors. The relative deviations have been estimated for realistic uncertainties for individual parameters. The results of the sensitivity study indicate that the total systematic error is dominated by aerosol and albedo for altitudes below $20 \mathrm{~km}$, i.e. up to $\pm 13 \%$ for aerosol at the northern polar latitudes and $\pm 7 \%$ for albedo in the tropics at $10 \mathrm{~km}$ altitude. The ozone retrieval errors associated with errors in tangent height, clouds, and pressure dominate the total systematic error for altitudes above $20 \mathrm{~km}$ and can lead to total systematic errors of the order of $\pm 5 \%$ at these altitudes. The contribution of uncertainties in temperature, the choice of ozone absorption cross section, and the temperature dependence of the ozone absorption cross section (T-ozone) to the total systematic error can be neglected. The random error is the a posteriori 
covariance standard deviation (APSD) for a defined SNR in our case. The total random error in the Northern Hemisphere ranges between \pm 34 (15 km, tropics) and $\pm 12 \%$ (40 km, polar region).

The total systematic and total random errors have been defined and calculated for the tropics, mid-latitudes, and polar latitudes. The total systematic error for the altitudes above $15 \mathrm{~km}$ is below 5,5 , and $8 \%$ in the polar region, midlatitudes, and tropics, respectively.

The total error budget is underestimated by neglecting the radiometric, spectroscopic, stray-light, and polarization effects on the ozone retrieval.

Our results indicate that incorrect knowledge of aerosol loading and surface albedo can affect the ozone profile retrievals dramatically for altitudes below $20 \mathrm{~km}$. Determination of exact tangent height is crucial, since any small uncertainty in the knowledge of tangent height can lead to fairly large systematic ozone deviations. The effects of pressure and temperature have to be considered with care for longterm ozone trends, where systematic trends in the thermodynamic parameters can impact the derived long-term trends.

The results of our analysis can be used as total error limits (systematic $=$ bias; random $=$ precision $)$ for validation and intercomparison tasks of SCIAMACHY ozone data with other concurrent instruments. The use of total error budget is important, especially for long-term investigations of ozone behaviour in a changing climate or validation between different instruments.

Acknowledgement. This work has been funded within the framework of the ESA project OZONE CCI (Climate Change Initiative). We would like to thank the SCIAMACHY and SCIATRAN group for providing the data and tools for this work. The suggestions and comments made by an anonymous referee and Douglas Degenstein have improved the paper, and we would like to thank them for their contribution.

Edited by: R. Eckman

\section{References}

Barker, H. W. and Davies, J. A.: Surface albedo estimates from Nimbus-7 ERB Data and a two-stream approximation of the radiative transfer equation, J. Climate, 2, 409-418, 1989.

Boccara, G., Hertzog, A., Basdevant, C., and Vial, F.: Accuracy of NCEP/NCAR reanalyses and ECMWF analyses in th lower stratosphere over Antarctica in 2005, J. Geophys. Res., 113, D20115, doi:10.1029/2008JD010116, 2008.

Bogumil, K., Orphal, J., Homann, T., Voigt, S., Spietz, P., Fleischmann, O. C., Vogel, A., Hartmann, M., Bovensmann, H., Frerick, J., and Burrows, J. P.: Measurements of molecular absorption spectra with the SCIAMACHY pre-flight model: instrument characterisation and reference data for atmospheric remotesensing in the $230-2380 \mathrm{~nm}$ region, J. Photochem. Photobio. A., 157, 157-167, 2003.
Bovensmann, H., Burrows, J. P., Buchwitz, M., Frerick, J., Noël, S., Rozanov, V. V., Chance, K. V., and Goede, A. P. H.: SCIAMACHY: mission objectives and measurement modes, J. Atmos. Sci., 56, 127-150, 1999.

Bovensmann, H., Ahlers, B., Buchwitz, M., Frerick, J., Gottwald, M., Hoogeveen, R., Kaiser, J. W., Kleipool, Q., Krieg, E., Lichtenberg, G., Mager, R., Meyer, J., Noël, S., Schlesier, A., Sioris, C., Skupin, J., von Savigny, C., Wuttke, M. W., and Burrows, J. P.: SCIAMACHY in-flight instrument performance, Proceedings of the Envisat Calibration Review (SP-520), ESA Publications Division, Frascati, Italy, 9-13 December, 2002.

Bracher, A., Bovensmann, H., Bramstedt, K., Burrows, J. P., von Clarmann, T., Eichmann, K.-U., Fischer, H., Funke, B., GilLopez, S., Glatthor, N., Grabowski, U., Höpfner, M., Kaufmann, M., Kellmann, S., Kiefer, M., Koukouli, M. E., Linden, A., Lopez-Puertas, M., Mengistu Tsidu, G., Milz, M., Noël, S., Rohen, G., Rozanov, A., Rozanov, V. V., von Savigny, C., Sinnhuber, M., Skupin, J., Steck, T., Stiller, G. P., Wang, D.-Y., Weber, M., and Wuttke, M. W.: Cross comparisons of $\mathrm{O}_{3}$ and $\mathrm{NO}_{2}$ measured by the atmospheric ENVISAT instruments GOMOS, MIPAS, and SCIAMACHY, Adv. Space Res., 36, 855867, doi:10.1016/j.asr.2005.04.005, 2005.

Burrows, J. P., Richter, A., Dehn, A., Deters, B., Himmelmann, S., Voigt, S., and Orphal, J.: Atmospheric remote-sensing reference data from GOME: 2. temperature-dependent absorption cross sections of $\mathrm{O}_{3}$ in the 231-794 nm range, J. Quant. Spectrosc. Radiat. Transfer, 61, 509-517, 1998.

Butz, A., Bösch, H., Camy-Peyret, C., Chipperfield, M., Dorf, M., Dufour, G., Grunow, K., Jeseck, P., Kühl, S., Payan, S., Pepin, I., Pukite, J., Rozanov, A., von Savigny, C., Sioris, C., Wagner, T., Weidner, F., and Pfeilsticker, K.: Inter-comparison of stratospheric $\mathrm{O}_{3}$ and $\mathrm{NO}_{2}$ abundances retrieved from balloon borne direct sun observations and Envisat/SCIAMACHY limb measurements, Atmos. Chem. Phys., 6, 1293-1314, doi:10.5194/acp-61293-2006, 2006.

Chapman, S.: A theory of upper-atmospheric ozone, Mem. R. Metrol. Soc., 3, 103-125, 1930.

Cortesi, U., Lambert, J. C., De Clercq, C., Bianchini, G., Blumenstock, T., Bracher, A., Castelli, E., Catoire, V., Chance, K. V., De Mazière, M., Demoulin, P., Godin-Beekmann, S., Jones, N., Jucks, K., Keim, C., Kerzenmacher, T., Kuellmann, H., Kuttippurath, J., Iarlori, M., Liu, G. Y., Liu, Y., McDermid, I. S., Meijer, Y. J., Mencaraglia, F., Mikuteit, S., Oelhaf, H., Piccolo, C., Pirre, M., Raspollini, P., Ravegnani, F., Reburn, W. J., Redaelli, G., Remedios, J. J., Sembhi, H., Smale, D., Steck, T., Taddei, A., Varotsos, C., Vigouroux, C., Waterfall, A., Wetzel, G., and Wood, S.: Geophysical validation of MIPASENVISAT operational ozone data, Atmos. Chem. Phys., 7, 48074867, doi:10.5194/acp-7-4807-2007, 2007.

Crutzen, P. J.: The influence of nitrogen oxides on the atmospheric ozone content, Q. J. Roy. Meteor. Soc., 96, 320-325, 1970.

Ernst, F., von Savigny, C., Rozanov, A., Rozanov, V., Eichmann, K.U., Brinkhoff, L. A., Bovensmann, H., and Burrows, J. P.: Global stratospheric aerosol extinction profile retrievals from SCIAMACHY limb-scatter observations, Atmos. Meas. Tech. Discuss., 5, 5993-6035, doi:10.5194/amtd-5-5993-2012, 2012. 
Flittner, D. E., Bhartia, P. K., and Herman, B. M.: Ozone profiles retrieved from limb scatter measurements: theory, Geophys. Res. Lett., 27, 2601-2604, 2000.

Froidevaux, L., Jiang, Y. B., Lambert, A., Livesey, N. J., Read, W. G., Waters, W., Browell, E. V., Hair, J. W., Avery, M. A., McGee, T. J, Twigg, L. W., Sumnicht, K. W., Margitan, J. J., Sen, B., Stachnik, R. A., Toon, G. C., Bernath, P. F., Boone, C. D., Walker, K. A., Filipiak, M. J., Harwood, R. S., Fuller, R. A., Manney, G. L., Schwartz, M. J., Daffer, W. H., Drouin, B. J., Cofield, R. E., Cuddy, D. T., Jarnot, R. F., Knosp, B. W., Perun, V. S., Snyder, W. V., Stek, P. C., Thurstans, R. P., and Wagner, P. A.: Validation of Aura Microwave Limb Sounder stratospheric ozone measurements, J. Geophys. Res., Vol. 113, D15S20, doi:10.1029/2007JD008771, 2008.

Fussen, D. and Bingen, C.: A volcanism dependent model for the extinction profile of stratospheric aerosols in the UV-visible range, Geophys. Res. Lett., 26, 703-706, 1999.

Hendrick, F., Van Roozendael, M., Kylling, A., Petritoli, A., Rozanov, A., Sanghavi, S., Schofield, R., von Friedeburg, C., Wagner, T., Wittrock, F., Fonteyn, D., and De Mazière, M.: Intercomparison exercise between different radiative transfer models used for the interpretation of ground-based zenith-sky and multi-axis DOAS observations, Atmos. Chem. Phys., 6, 93-108, doi:10.5194/acp-6-93-2006, 2006.

Jones, A., Urban, J., Murtagh, D. P., Eriksson, P., Brohede, S., Haley, C., Degenstein, D., Bourassa, A., von Savigny, C., Sonkaew, T., Rozanov, A., Bovensmann, H., and Burrows, J.: Evolution of stratospheric ozone and water vapour time series studied with satellite measurements, Atmos. Chem. Phys., 9, 6055-6075, doi::10.5194/acp-9-6055-2009, 2009.

Kiehl, J. T. and Trenberth, K. E.: Earth's annual global mean energy budget, B. Am. Meteor. Soc., 78, 197-208, 1997.

Kurosu, T., Rozanov, V. V., and Burrows, J. P.: Parameterization schemes for terrestrial water clouds in the radiative transfer model GOMETRAN, J. Geophys. Res., 102, 21809-21823, 1997.

Loughman, R. P., Griffioen, E., Oikarinen, L., Postylyakov, O. V., Rozanov, A., Flittner, D. E., and Rault, D. F.: Comparison of radiative transfer models for limb-viewing scattered sunlight measurements, J. Geophys. Res., 109, D06303, doi:10.1029/2003JD003857, 2004.

Masiello, G., Matricardi, M., and Serio, C.: The use of IASI data to identify systematic errors in the ECMWF forecasts of temperature in the upper stratosphere, Atmos. Chem. Phys., 11, 10091021, doi:10.5194/acp-11-1009-2011, 2011.

Matthews, E.: Global vegetation and land use: new high resolution data bases for climate studies, J. Appl. Meteorol., 22, 474-487, 1983.

Mieruch, S., Weber, M., von Savigny, C., Rozanov, A., Bovensmann, H., Burrows, J. P., Bernath, P. F., Boone, C. D., Froidevaux, L., Gordley, L. L., Mlynczak, M. G., Russell III, J. M., Thomason, L. W., Walker, K. A., and Zawodny, J. M.: Global and long-term comparison of SCIAMACHY limb ozone profiles with correlative satellite data (2002-2008), Atmos. Meas. Tech., 5, 771-788, doi:10.5194/amt-5-771-2012, 2012.

Molina, M. and Rowland, F.: Stratospheric sinks for cholorfluoromethanes: chlorine atom-catalyzed destruction of ozone, Nature, 249, 810-812, 1974.
Newchurch, M. J., Yang, E. S., Cunnold, D. M., Reinsel, G. C., Zawodny, J. M., and Russell III, J. M.: Evidence for slowdown in stratospheric ozone loss: first stage of ozone recovery, J. Geophys. Res., 108, 4507, doi:10.1029/2003JD003471, 2003.

Nowlan, R. C.: Atmospheric Temperature and Pressure Measurements from the ACE-MAESTRO Space Instrument, Ph.D. Thesis, University of Toronto, Toronto, Canada, 2006.

Rault, D. F., and Taha, G.: Validation of ozone profiles retrieved from Stratospheric Aerosol and Gas Experiment III limb scatter measurements, J. Geophys. Res., Vol. 112, D13309, doi:10.1029/2006JD007679, 2007.

Remer, L. A., Kaufman, Y. J., Levin, Z., and Ghan, S.: Model assessment of the ability of MODIS to measure top-of-atmosphere direct radiative forcing from smoke aerosols, J. Atmos. Sci., 59, 657-667, 2002.

Rodgers, C. D.: Characterization and error analysis of profiles retrieved from remote sounding measurements, J. Geophys. Res., 95, 5587-5595, 1990.

Rozanov, A., Rozanov, V. V., and Burrows, J. P.: A numerical radiative transfer model for a spherical planetary atmosphere: combined differential-integral approach involving the Picard iterative approximation, J. Quant. Spectrosc. Ra., 69, 491-512, 2001.

Rozanov, A., Bovensmann, H., Bracher, A., Hrechanyy, S., Rozanov, V. V., Sinnhuber, M., Stroh, F., and Burrows, J. P.: $\mathrm{NO}_{2}$ and $\mathrm{BrO}_{2}$ vertical profile retrieval from SCIAMACHY limb measurements: sensitivity studies, Adv. Space Res., 36, 846-854, doi:10.1016/j.asr.2005.03.013, 2005a.

Rozanov, A., Rozanov, V. V., Buchwitz, M., Kokhanovsky, A., and Burrows, J. P.: SCIATRAN 2.0 - a new radiative transfer model for geophysical applications in the $175-2400 \mathrm{~nm}$ spectral region, Adv. Space Res., 36, 1015-1019, 2005b.

Rozanov, A., Eichmann, K.-U., von Savigny, C., Bovensmann, H., Burrows, J. P., von Bargen, A., Doicu, A., Hilgers, S., GodinBeekmann, S., Leblanc, T., and McDermid, I. S.: Comparison of the inversion algorithms applied to the ozone vertical profile retrieval from SCIAMACHY limb measurements, Atmos. Chem. Phys., 7, 4763-4779, doi:10.5194/acp-7-4763-2007, 2007.

Rozanov, V. V. and Kokhanovsky, A. A.: Determination of cloud geometrical thickness using backscattered solar light in a gaseous absorption band, IEEE Geosci. Remote S., 3, 250-253, 2006.

Rozanov, V. V. and Kokhanovsky, A. A.: Impact of single- and multi-layered cloudiness on ozone vertical column retrievals using nadir observations of backscattered solar radiation, in: Light Scattering Reviews 3, Springer, Praxis Publishing, Chichester, UK, 133-189, 2008.

Rozanov, V. V., Diebel, D., Spurr, R., and Burrows, J. P.: GOMETRAN: a radiative transfer model for the satellite project GOME - the plane-parallel version, J. Geophys. Res., 102, 16683$16695,1997$.

Siewert, C. E.: A discrete-ordinates solution for radiative-transfer models that include polarization effects, J. Quant. Spectrosc. Ra., 64, 227-254, 2000.

Sonkaew, T., Rozanov, V. V., von Savigny, C., Rozanov, A., Bovensmann, H., and Burrows, J. P.: Cloud sensitivity studies for stratospheric and lower mesospheric ozone profile retrievals from measurements of limb-scattered solar radiation, Atmos. Meas. Tech., 2, 653-678, doi:10.5194/amt-2-653-2009, 2009.

Steinbrecht, W., Claude, H., Schönborn, F., McDermid, I. S., Leblanc, T., Godin-Beekmann, S., Keckhut, P., Hauchecorne, A., 
Gijsel, J. A. E. V., Swart, D. P. J., Bodeker, G. E., Parrish, A., Boyd, I. S., Kämpfer, N., Hocke, K., Stolarski, R. S., Frith, S. M., Thomason, L. W., Remsberg, E. E., von Savigny, C., Rozanov, A., and Burrows, J. P.: Ozone and temperature trends in the upper stratosphere at five stations of the network for the detection of atmospheric composition change, Int. J. Remote Sens., 30, 3875-3886, 2009.

Steinbrecht, W., Köhler, U., Claude, H., Weber, M., Burrows, J. P., and van $\operatorname{der}$ A, R. J.: Very high ozone columns at northern mid-latitudes in 2010, Geophys. Res. Lett., 38, L06803, doi:10.1029/2010GL046634, 2011.

von Clarmann, T.: Validation of remotely sensed profiles of atmospheric state variables: strategies and terminology, Atmos. Chem. Phys., 6, 4311-4320, doi:10.5194/acp-6-4311-2006, 2006.

von Savigny, C., Haley, C. S., Sioris, C. E., McDade, I. C., Llewellyn, E. J., Degenstein, D., Evans, W. F. J., Gattinger, R. L., Griffioen, E., Kyrölä, E., Lloyd, N. D., McConnell, J. C., McLinden, C. A., Mégie, G., Murtagh, D. P., Solheim, B., and Strong, K.: Stratospheric ozone profiles retrieved from limb scattered sunlight radiance spectra measured by the OSIRIS instrument on the Odin satellite, Geophys. Res. Lett., 30, 1755, doi:10.1029/2002GL016401, 2003.

von Savigny, C., Rozanov, A., Bovensmann, H., Eichmann, K.-U., Noël, S., Rozanov, V. V., Sinnhuber, B.-M., Weber, M., Burrows, J. P., and Kaiser, J. W.: The ozone hole breakup in september 2002 as seen by SCIAMACHY on ENVISAT, J. Atmos. Sci., 62, 721-734, 2005a. von Savigny, C., McDade, I. C., Griffioen, E., Haley, C. S., Sioris, C. E., and Llewellyn, E. J.: Sensitivity studies and first validation of stratospheric ozone profile retrievals from Odin/OSIRIS observations of limb-scattered solar radiation, Can. J. Phys., 83, 9, 957-972, 2005b.

von Savigny, C., Bovensmann, H., Bramstedt, K., Dikty, S., Ebojie, F., Jones, A., Noël, S., Rozanov, A., and Sinnhuber, B.-M.: Indications for long-term trends and seasonal variations in the SCIAMACHY Level 1 version 6.03 tangent height information, Techn. Note IUP scia pointing 2009-01, Issue 2, University of Bremen, Bremen, Germany, 2009.

Wagner, T., Burrows, J. P., Deutschmann, T., Dix, B., von Friedeburg, C., Frieß, U., Hendrick, F., Heue, K.-P., Irie, H., Iwabuchi, H., Kanaya, Y., Keller, J., McLinden, C. A., Oetjen, H., Palazzi, E., Petritoli, A., Platt, U., Postylyakov, O., Pukite, J., Richter, A., van Roozendael, M., Rozanov, A., Rozanov, V., Sinreich, R., Sanghavi, S., and Wittrock, F.: Comparison of box-airmass-factors and radiances for Multiple-Axis Differential Optical Absorption Spectroscopy (MAX-DOAS) geometries calculated from different UV/visible radiative transfer models, Atmos. Chem. Phys., 7, 1809-1833, doi:10.5194/acp-7-1809-2007, 2007.

WMO: Assessment, Scientific Assessment of Ozone Depletion: 2006, 50, World Meteorological Organization, Geneva, Switzerland, 2006. 